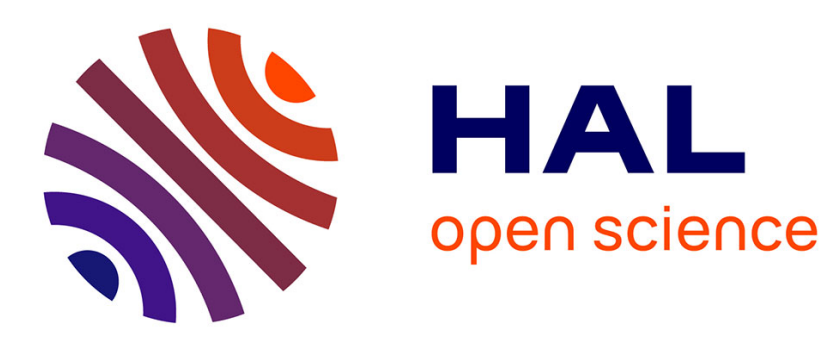

\title{
Changes in atmospheric chemistry and crop health: A review
}

Bender, Weigel

\section{To cite this version:}

Bender, Weigel. Changes in atmospheric chemistry and crop health: A review. Agronomy for Sustainable Development, 2011, 31 (1), pp.81-89. 10.1051/agro/2010013 . hal-00930472

\section{HAL Id: hal-00930472 \\ https://hal.science/hal-00930472}

Submitted on 1 Jan 2011

HAL is a multi-disciplinary open access archive for the deposit and dissemination of scientific research documents, whether they are published or not. The documents may come from teaching and research institutions in France or abroad, or from public or private research centers.
L'archive ouverte pluridisciplinaire HAL, est destinée au dépôt et à la diffusion de documents scientifiques de niveau recherche, publiés ou non, émanant des établissements d'enseignement et de recherche français ou étrangers, des laboratoires publics ou privés. 


\title{
Review article
}

\section{Changes in atmospheric chemistry and crop health: A review}

\author{
Jürgen BENDER*, Hans-Joachim WEIGEL \\ Institute of Biodiversity, Johann Heinrich von Thünen-Institute (vTI), Federal Research Institute for Rural Areas, Forestry and Fisheries, \\ Bundesallee 50, 38116 Braunschweig, Germany
}

(Accepted 19 March 2010)

\begin{abstract}
The concentrations of atmospheric compounds such as greenhouse gases, heavy metals and trace gas air pollutants have rapidly changed. Many of these compounds interact with agricultural systems and influence crop performance, both directly by affecting growth and quality or indirectly by altering the plant's ability to cope with other abiotic and biotic stresses. Some atmospheric compounds have little or no discernible impact on the environment; others reach levels that exceed thresholds for damage to crops. In this review, we analyse the literature on airborne species that directly impact crop growth and health. In Europe and North America emissions of $\mathrm{SO}_{2}, \mathrm{NOx}$ and heavy metals have declined during the past decades and are currently not considered as a major threat to crops. By contrast, air pollutant emissions have been increasing in rapidly growing regions of Asia, Africa and Latin America. Ozone is the most phytotoxic of the common air pollutants. The widespread distribution of $\mathrm{O}_{3}$ already presents a risk to crop growth and health in many regions of the world. It is concluded that the continuous increase in background $\mathrm{O}_{3}$ concentrations will pose a critical threat to future world food security. Interactions with both biotic and abiotic factors must be taken into account in assessing risks of air pollutants in the field. There is evidence that these indirect effects could be more important under certain circumstances than the direct effects of air pollutants on plants. The parallel rapid increase in atmospheric $\mathrm{CO}_{2}$ concentrations accompanied by climate change has two major implications: (1) a possible benefit to crop growth by direct stimulation of photosynthesis and by mitigation of gaseous air pollutants and water stress; and (2) a threat to crop production due to an enhancement of crop quality losses.
\end{abstract}

atmospheric change / carbon dioxide / crops / ozone / pollutant interactions / product quality / yield

\section{Contents}

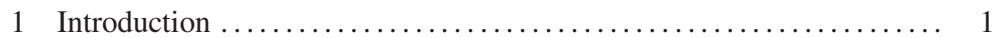

2 Spatial and temporal trends of atmospheric changes $\ldots \ldots \ldots \ldots \ldots . . \ldots 2$

3 Crop responses to atmospheric trace gases ................ 3

3.1 Direct effects on crop growth and yield ................ 3

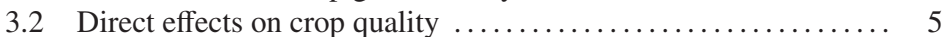

3.3 Interactive effects of atmospheric compounds ........... 6

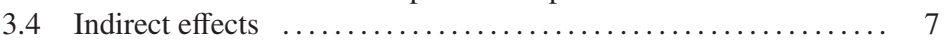

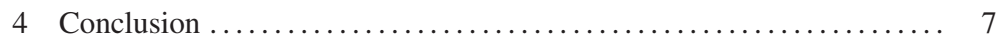

\section{INTRODUCTION}

Anthropogenic activities have significantly changed the composition of the global atmosphere. Especially, the concentrations of several trace gases have undergone significant changes during the past century and continue to change.

* Corresponding author: juergen.bender@vti.bund.de
Plants are important mediators in the exchange of the different gaseous and particulate compounds between the atmosphere and the biosphere (Tab. I). The transport of these compounds from the atmosphere into vegetation is by dry and wet deposition of gases, aerosols and sedimenting particles. Many atmospheric constituents can influence crop performance, both directly by affecting growth and quality or indirectly by altering the plant's ability to cope with other abiotic and biotic stresses. In terms of their impact on agricultural ecosystems 
Table I. Atmospheric compounds involved in element flux between vegetation and the atmosphere (after Dämmgen and Weigel, 1998).

\begin{tabular}{ll}
$-\mathrm{H}_{2} \mathrm{O}$ vapour, $\mathrm{CO}_{2}, \mathrm{CH}_{4}, \mathrm{~N}_{2} \mathrm{O}, \mathrm{NO}_{2}, \mathrm{O}_{3} \rightarrow$ & $\begin{array}{l}\text { trapping of infrared radiation, } \\
\text { contribution to the greenhouse effect } \\
\text { effects on reactivity of the atmosphere }\end{array}$ \\
- $\mathrm{NH}_{3}, \mathrm{CO}, \mathrm{HC} \rightarrow$ & $\begin{array}{l}\text { involved in nutrient cycling, } \\
\text { - } \mathrm{CH}_{4} \mathrm{CO}_{2}, \mathrm{SO}_{2}, \mathrm{NO}_{2}, \mathrm{NO}, \mathrm{NH}_{3} \text { (gases) } \rightarrow\end{array}$ \\
$\mathrm{NH}_{4}-\mathrm{NO}_{3}-\mathrm{N}, \mathrm{SO}_{4} \mathrm{~S}, \mathrm{P}, \mathrm{Ca}, \mathrm{K}$, & \\
$\mathrm{Fe}, \mathrm{Mg}$ (particles) & potentially toxic, affecting "normal" \\
$-\mathrm{O}_{3}, \mathrm{SO}_{2}, \mathrm{NO}_{2}, \mathrm{HF}, \mathrm{H}_{2} \mathrm{O}_{2}, \mathrm{PAN}, \rightarrow$ & growth and performance of organisms, \\
& $\mathrm{NMHC} / \mathrm{VOC}$ (gases), heavy metals \\
(e.g., $\mathrm{Pb}, \mathrm{Cd}, \mathrm{Hg}$ ), surplus nutrients & populations and ecosystems \\
(bioavailable forms of $\mathrm{N}, \mathrm{S}, \mathrm{Zn}, \mathrm{Al})$ & \\
\hline
\end{tabular}

Abbreviations: $\mathrm{Al}$ : aluminum; Ca: calcium; Cd: cadmium; $\mathrm{CH}_{4}$ : methane; $\mathrm{CO}$ : carbon monoxide; $\mathrm{CO}_{2}$ : carbon dioxide; Fe: iron; $\mathrm{HC}$ : hydrocarbons; $\mathrm{HF}$ : fluoride; $\mathrm{Hg}$ : mercury; $\mathrm{H}_{2} \mathrm{O}$ : water vapour; $\mathrm{H}_{2} \mathrm{O}_{2}$ : hydrogen peroxide; $\mathrm{H}_{2} \mathrm{~S}$ : hydrogen sulphide; $\mathrm{K}$ : potassium; $\mathrm{Mg}$ : magnesium; $\mathrm{N}$ : nitrogen; $\mathrm{N}_{2} \mathrm{O}$ : nitrous oxide; $\mathrm{NH}_{3}$ : ammonia; $\mathrm{NH}_{4}^{+}$: ammonium; $\mathrm{NO}$ : nitrogen monoxide; $\mathrm{NO}_{2}$ : nitrogen dioxide; $\mathrm{NO}_{3}^{-}$: nitrate; $\mathrm{NO}_{X}$ : $\mathrm{NO}_{+}+\mathrm{NO}$; $\mathrm{NMHC}_{3}$ : nonmethane hydrocarbons; $\mathrm{O}_{3}$ : ozone; $\mathrm{P}$ : phosphorus; $\mathrm{PAN}$ : peroxyacetylnitrate; $\mathrm{Pb}$ : lead; $\mathrm{S}$ : sulphur; $\mathrm{SO}_{2}$ : sulphur dioxide; $\mathrm{SO}_{4}^{2-}$ : sulphate; VOC: volatile organic compounds; $\mathrm{Zn}$ : zinc.

the atmospheric compounds (for abbreviations see Tab. I) can be broadly divided into:

- compounds which act as macro- or micronutrients, e.g., the gases $\mathrm{CO}_{2}, \mathrm{SO}_{2}, \mathrm{NO}, \mathrm{NO}_{2}$ and $\mathrm{NH}_{3}$ and particulate $\mathrm{NH}_{4}$, $\mathrm{NO}_{3}-\mathrm{N}, \mathrm{SO}_{4}-\mathrm{S}, \mathrm{P}, \mathrm{Ca}, \mathrm{Fe}$ and $\mathrm{Mg}$, and

- compounds which may cause adverse or toxic effects, e.g., the gaseous pollutants $\mathrm{O}_{3}, \mathrm{SO}_{2}, \mathrm{NO}_{2}, \mathrm{NH}_{3}, \mathrm{HF}, \mathrm{PAN}$, NMHC and VOC, metals such as $\mathrm{Pb}, \mathrm{Cd}$ and $\mathrm{Hg}$, or excess nutrient substances, e.g., N, S, Zn and Al, which alter normal patterns of growth and development in ecosystems (Dämmgen and Weigel, 1998).

There are both natural and human-made sources for most of the atmospheric constituents. An air pollutant is usually defined as "a chemical constituent added to the atmosphere through human activities resulting in the elevation of its concentration above a background" (Krupa, 1997).

In this review, we focus on those airborne species whose concentrations have a known trend and are directly interfering with agroecosystems. Ambient air is always composed of mixtures of different species, with the concentrations of individual species or pollutants, respectively, varying in time and with location. For example, a particular air pollutant such as $\mathrm{SO}_{2}, \mathrm{HF}$ or $\mathrm{NH}_{3}$ can be dominant only in the vicinity of its sources, i.e. those pollutants are primarily of local importance. In comparison, among secondary pollutants, $\mathrm{O}_{3}$ is of widespread global occurrence and can currently be considered to be the most important air pollutant (Fuhrer, 2009). Among the different environmental factors which determine crop growth, recent and predicted further changes in climate such as increased temperature, altered pattern of rainfall intensity and frequency, and atmospheric $\mathrm{CO}_{2}$ concentration as well as other atmospheric compounds have become and will be of growing importance in many parts of the world. Therefore, projections of future global food security must equally consider the likely impacts of climate change and air pollution. With respect to effects, responses of crops to $\mathrm{O}_{3}$ and $\mathrm{CO}_{2}$ are particularly considered here as these trace gases are key variables of climatic and atmospheric change for future global food production (Long et al., 2005; Vandermeiren et al., 2009).

\section{SPATIAL AND TEMPORAL TRENDS OF ATMOSPHERIC CHANGES}

The concentrations of $\mathrm{SO}_{2}$, nitrogen oxides (NOx) and VOCs as well as of heavy metals and photochemical oxidants such as $\mathrm{O}_{3}$ in many parts of the industrialised world have changed significantly during the last century (Dämmgen and Weigel, 1998). While local emissions of urban or industrial sources still occur, emissions, particularly of $\mathrm{SO}_{2}$ and to a smaller extent of $\mathrm{NOx}\left(\mathrm{NO}+\mathrm{NO}_{2}\right)$, VOCs and particulate matter, have declined during the past decades in Europe and North America. This was due to successful policies to reduce emissions, as well as a decline in polluting heavy industries (UNECE, 2007). For example, emissions of $\mathrm{SO}_{2}$ throughout Western Europe have declined by approximately $80 \%$ since the peak in emissions during the 1970s (Fowler et al., 2001). $\mathrm{SO}_{2}$ levels and sulphur bulk deposition are now usually low during the growth periods of crops. At present, annual mean $\mathrm{SO}_{2}$ concentrations in Europe are less than $10 \mu \mathrm{g} \mathrm{m}^{-3}$ and rarely exceed $50 \mu \mathrm{g} \mathrm{m}^{-3} \mathrm{SO}_{2}$, and bulk $\mathrm{S}$ depositions are lower than $10-15 \mathrm{~kg} \mathrm{ha}^{-1} \mathrm{a}^{-1}$ (Fowler et al., 2001). Emission estimates of atmospheric nitrogen species $\left(\mathrm{NOx}, \mathrm{NH}_{3}\right.$ ) are more uncertain because of the variety of gases and sources (Grübler, 2003). However, the concentrations in oxidised atmospheric $\mathrm{N}$ compounds also show a declining trend although NOx concentrations are highly variable due to different local traffic densities (UNECE, 2007). In rural regions of Europe annual mean concentrations for $\mathrm{NO}_{2}$ range between 5 and $30 \mu \mathrm{g} \mathrm{m}^{-3}$ and less than $5 \mu \mathrm{g} \mathrm{m}^{-3}$ for NO (Dämmgen and Weigel, 1998). Currently, the emissions of $\mathrm{NH}_{3}$ from farm land determine the concentrations of this gas in the air above these systems. The concentrations range from 1 to $30 \mu \mathrm{g} \mathrm{NH}_{3}$, if one excludes periods with applications of liquid manure or slurry. Concentrations of airborne VOCs are also highly diverse and the evaluation of their occurrence and distribution is difficult, because there are both anthropogenic and biogenic sources, the latter including emissions from plant, animal and microbial sources (Kesselmeier and Staudt, 1999; Cape, 2003; Krupa et al., 2008). Average annual concentrations of the major airborne VOCs benzene, toluene and ethylene are usually lower than 
$5 \mu \mathrm{g} \mathrm{m}^{-3}$, although maximum hourly concentrations of some VOCs can be 100 times larger than the average (Collins and Bell, 2002; Cape, 2003). For the majority of heavy metals such as $\mathrm{Pb}, \mathrm{Cd}, \mathrm{Ni}, \mathrm{Hg}$ and $\mathrm{Zn}$ a similar decline in emission and subsequent deposition has been observed since the late 1980s in most of Europe, although higher metal deposition is still found in some Eastern European countries (Harmens et al., 2008).

In contrast to the situation in Europe and North America, air pollutant emissions have been increasing over the last two decades in many developing countries, particularly in rapidly growing regions of Asia, Africa and Latin America, where rapid industrialisation and population growth is taking place accompanied by increasing energy demand and road traffic, but with poor emission controls (Emberson et al., 2003). China and India are now the leading emitters of $\mathrm{SO}_{2}$ in the world (Marshall, 2002). Also, the predicted increase in global NOx emissions may be attributed largely to the high percentage increases in developing countries, such as China (Marshall, 2002; Ghude et al., 2009).

Nitrogen oxides and VOCs are important precursors for the formation of tropospheric $\mathrm{O}_{3}$. Tropospheric $\mathrm{O}_{3}$ is a widespread secondary air pollutant found in all industrialised countries worldwide, and meanwhile also in many of the developing countries in the world, where it has reached levels in ambient air which are of concern with respect to vegetation damage and human health effects (Emberson et al., 2003; Royal Society, 2008), and these trends are expected to continue as economies continue to expand. While at least in most parts of Western Europe there is a clear trend of decreasing $\mathrm{O}_{3}$ peak values ("photosmog episodes"), predictive models indicate that background $\mathrm{O}_{3}$ concentrations will continue to increase at a rate of $0.5 \%$ to $2 \%$ per year in the Northern Hemisphere during the next several decades. Currently, the background $\mathrm{O}_{3}$ concentration in the Northern hemisphere is within the range of 23$34 \mathrm{ppb}$; however, global surface $\mathrm{O}_{3}$ concentration is expected to be in the range of $42-84 \mathrm{ppb}$ by 2100 (Vingarzan, 2004). Figure 1 shows the projected global increase in $\mathrm{O}_{3}$ concentration over the next 100 years from Prather et al. (2003), based on IPCC global emission scenarios. According to these, the locations of the major $\mathrm{O}_{3}$ increases ("hot-spots") in the future are expected to be Asia, Southern Africa, Southern Europe and the USA.

In contrast to the different temporal trends of the "classical" air pollutants such as $\mathrm{SO}_{2}$ and $\mathrm{NOx}$ between industrialised and developing countries and the respective spatial variability in their concentration levels, atmospheric $\mathrm{CO}_{2}$ concentration has risen steadily all over the globe from a pre-industrial concentration of about $280 \mathrm{ppm}$ to a current value of about $385 \mathrm{ppm}$, and could reach more than $550 \mathrm{ppm}$ by 2050 (IPCC, 2007). Due to the direct effects of rising $\mathrm{CO}_{2}$ levels on crop photosynthesis, growth and quality, assessments of future air pollution effects on plants and crops have to consider this rapid change.

Overall, the concentrations of sulphur and nitrogen-based air pollutants and of heavy metals have declined during the past decades in many countries of Europe and North America. By contrast, air pollutant emissions have been increasing in rapidly growing regions of Asia, Africa and Latin America. Tropospheric $\mathrm{O}_{3}$, however, is still at high levels worldwide.

\section{CROP RESPONSES TO ATMOSPHERIC TRACE GASES}

\subsection{Direct effects on crop growth and yield}

Gaseous atmospheric compounds are transferred from the atmosphere onto plant canopies by diffusion, which is governed by micro-meteorological conditions (radiation, temperature, wind, etc.). The major path of entry into the leaf is through the stomata. The other two pathways are non-stomatal pathways, which include deposition on external plant surfaces including the cuticle and deposition on the soil (Fig. 2). Penetration of gases through plant cuticles is usually of minor importance (Lendzian and Kerstiens, 1991), although some pollutants such as $\mathrm{SO}_{2}$ are able to damage the cuticle and gain entry to the internal leaf tissue to some extent (Wellburn, 1994). Aerosols and sedimenting particles containing nutrients and pollutants (e.g., heavy metals) are deposited on plant surfaces or on soil surfaces directly; matter deposited on plant surfaces indirectly can be transferred to the soil by run-off or by plant debris or litter. After entering the root zone they are available for plant uptake. The reaction of a plant to a given air pollutant depends on the exposure characteristics, plant properties and external growth conditions (Krupa, 1997; Bender and Weigel, 2003). Short-term exposures to relatively high concentrations generally result in acute visible foliar injury. Long-term chronic exposures to lower concentrations can cause alterations in physiological and biochemical processes that may result in chlorosis, premature senescence, and growth and yield reductions.

For example, while exposure to short-term high concentrations of $\mathrm{SO}_{2}$ can lead to cellular death, exposure to low to moderate $\mathrm{SO}_{2}$ concentrations over the long term can result in impaired cellular metabolism, an accumulation of sulphate in the vacuole, and a reduction in photosynthetic rate (Legge et al., 1998). Sensitivity of plants to $\mathrm{SO}_{2}$ is generally determined by mesophyll resistance and by buffering capacities (i.e. the ability to counteract a change in $\mathrm{pH}$ from an optimal value; Wellburn, 1994). However, current ambient $\mathrm{SO}_{2}$ concentrations in Europe can no longer be considered as a serious problem with respect to negative effects on plant performance. The few data describing exposure-response relationships for long-term (weeks to months) exposure to low and moderate $\mathrm{SO}_{2}$ concentrations (50 to $100 \mu \mathrm{g} \mathrm{m}^{-3}$ ) on crop growth and yield are somewhat variable and controversial (Weigel et al., 1990; Legge and Krupa, 2002). The overall evidence from fumigation studies shows that for most annual crop species ambient $\mathrm{SO}_{2}$ concentrations are below the critical levels above which adverse effects occur (UNECE, 2004). The reduction in $\mathrm{SO}_{2}$ emissions in Europe and North America has even resulted in the occurrence of sulphur deficiency in some agricultural species (e.g., rape) growing in sulphur-deficient areas (Legge and Krupa, 2002).

Similarly, phytotoxic effects of reactive nitrogen species (NO, $\mathrm{NO}_{2}, \mathrm{NH}_{3}$ ), particularly on crops, can only be observed at concentrations which are far above those occurring even in heavily polluted environments (Wellburn, 1994; UNECE, 2004). Exposure to moderate levels of $\mathrm{NO}_{2}$ can stimulate 

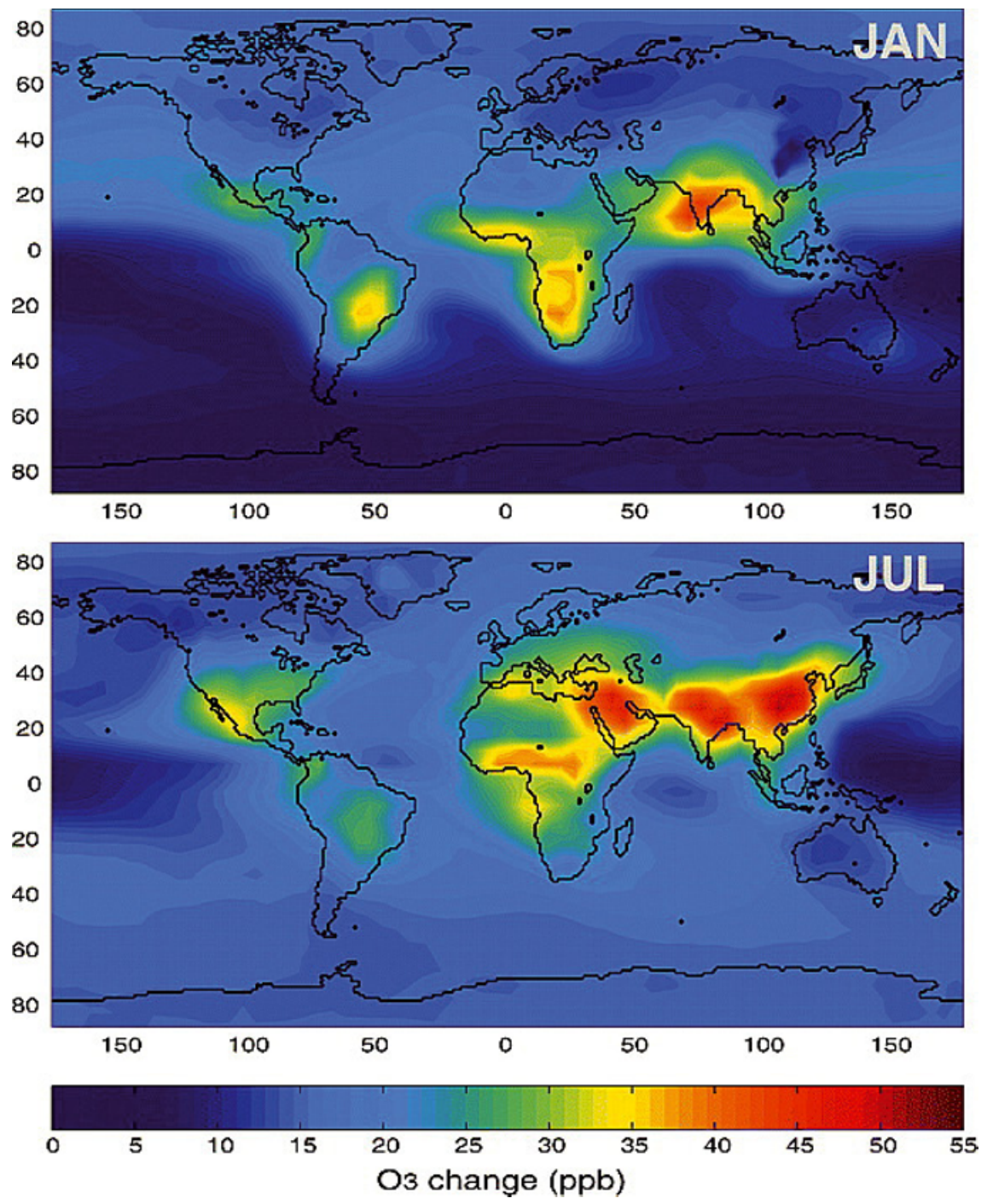

Figure 1. Predicted changes in global surface $\mathrm{O}_{3}$ concentration from 2000 to 2100 . The figure shows the averaged changes in $\mathrm{O}_{3}$ concentrations (ppb) for January and July. Blue colours denote no or little change while green to red colours point to a medium to severe increase in $\mathrm{O}_{3}$ concentrations. Adapted from Prather et al. (2003).

certain metabolic processes (e.g., enzyme activities), which indicates that airborne nitrogen derived from $\mathrm{NO}_{2}$ can be incorporated into the plant's nitrogen metabolism (Wellburn, 1990; Bender et al., 1991). At current rural concentrations, $\mathrm{NO}_{2}$ is unlikely to be phytotoxic but may act, to some extent, as an additional source of $\mathrm{N}$ (Davison and Cape, 2003). Also, the concentrations of $\mathrm{NH}_{3}$ in rural areas cannot be considered as a problem for crop growth, although there is some evidence that high and low temperatures or drought stress can considerably modify the effects of $\mathrm{NH}_{3}$ (Cape et al., 2008). Overall, in highly fertilised agricultural systems across Europe atmospheric nitrogen $\left(\mathrm{NO}_{2} / \mathrm{NO}, \mathrm{NH}_{3}\right)$ and sulphur $\left(\mathrm{SO}_{2}, \mathrm{H}_{2} \mathrm{~S}\right)$ compounds at current ambient levels cannot be considered as a direct threat for annual crops. By contrast, the few research findings from experiments performed in some developing countries of South and East Asia so far suggest that these pollutants can already lead to serious reductions of crop growth and yield, a situation which may be exacerbated in the future (Marshall, 2002; Ishii et al., 2004; Fu et al., 2007).

Considering current concentrations of VOCs, especially in rural areas, direct impacts of most of these compounds on crops are unlikely or unknown. Experiments to study the direct effects of VOCs on plants are usually performed in the laboratory and have used very high concentrations relative to ambient air (Cape, 2003). While a wide range of tolerance to airborne VOCs among plant species has been demonstrated, a few experiments have shown specific effects, particularly of ethylene (a plant hormone), on reproductive stages (seed germination, flowering, fruit ripening) (Collins and Bell, 2002; Cape, 2003).

For agriculture, chronic effects of air pollutants such as $\mathrm{O}_{3}$ are of particular concern, because they are due to exposures for weeks, months, or over the entire lifecycle of the crop. It is well known that increasing $\mathrm{O}_{3}$ levels cause a decline 


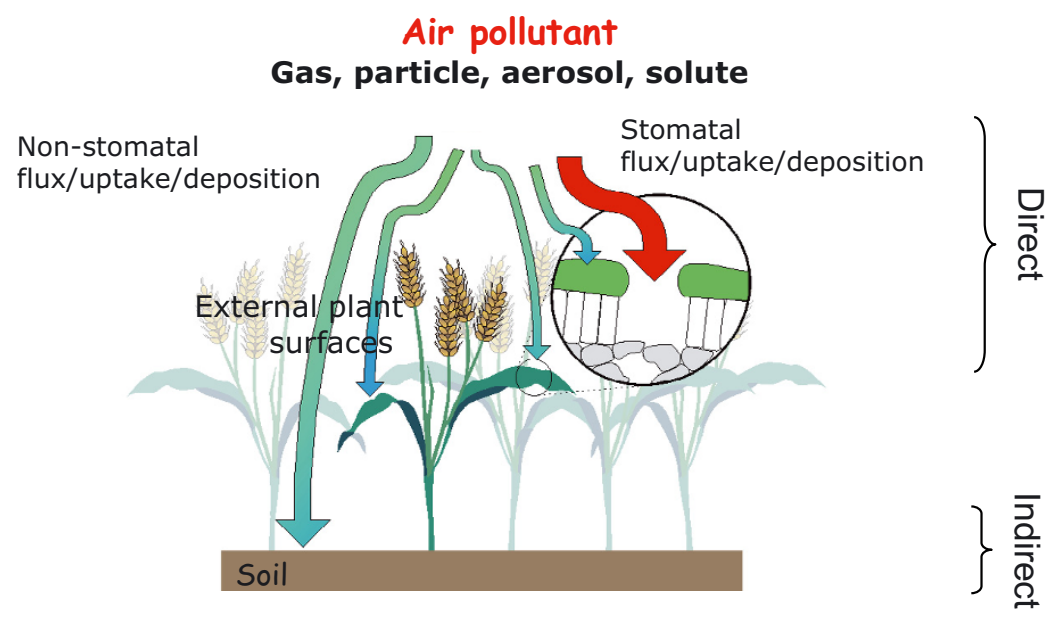

Figure 2. Major pathways of the transfer of air pollutants to terrestrial surfaces (plant canopies and soil). The thickness of the arrows denotes the relative importance of the respective pathway. Redrawn by courtesy of Dr. Lisa Emberson, SEI York, UK.

in the yield of many crop species, such as wheat, rice, soybean and cotton (Ashmore, 2005). Such yield losses have been attributed to reduced photosynthetic rate, altered carbon allocation and accelerated leaf senescence (Fiscus et al., 2005; Fuhrer, 2009). Recently, Mills et al. (2007) analysed $\mathrm{O}_{3}$ exposure-response data for 19 agricultural and horticultural crops, respectively, and identified wheat, water melon, pulses, cotton, turnip, tomato, onion, soybean and lettuce as the most ozone-sensitive crops, while, for instance, barley was classified as $\mathrm{O}_{3}$-resistant. Holland et al. (2006) estimated crop losses and the associated economic loss in Europe for 23 horticultural and agricultural crops for the base year 2000 and found an overall loss of $3 \%$ of all crop species considered, which would be equivalent to $€ 6.7$ billion economic damage. The global impact of $\mathrm{O}_{3}$ on crop yields was recently evaluated by Van Dingenen et al. (2009). Their estimates of present day global relative yield losses ranged between $7 \%$ and $12 \%$ for wheat, between $6 \%$ and $16 \%$ for soybean, between $3 \%$ and $4 \%$ for rice, and between $3 \%$ and $5 \%$ for maize. When translating the production losses into global economic damage for the four crops considered, they estimated an economic loss in the range of \$14-26 billion. About $40 \%$ of this damage is occurring in China and India. However, the uncertainty on these estimates is large. This is primarily due to the $\mathrm{O}_{3}$ exposure metrics used in the estimates, which are based on the exposure concentrations in ambient air, either on a regional, national or global scale, rather than on the actual uptake of $\mathrm{O}_{3}$ and thus do not account for the dose-specific nature of plant responses. In addition, only the direct $\mathrm{O}_{3}$ effects on crop growth are considered, while indirect growth effects, e.g., mediated by phytosanitary problems, are not taken into account (see Sect. 3.3). Moreover, wide variability in $\mathrm{O}_{3}$ sensitivity among various cultivars of a crop is common (USEPA, 2006). In summary, tropospheric $\mathrm{O}_{3}$ remains the most important atmospheric pollutant that has direct negative effects on many crop species worldwide.

By contrast, the continuous rise in atmospheric $\mathrm{CO}_{2}$ levels will principally have a positive effect on crop growth and yield, as $\mathrm{CO}_{2}$ directly affects plant physiology and growth by serving as a primary substrate for photosynthesis. Generally, elevated $\mathrm{CO}_{2}$ concentrations can increase biomass and yield in $\mathrm{C}_{3}$ crops by increasing photosynthesis and decreasing photorespiration, but with large differences among species in the magnitude of the yield stimulation (Amthor, 2001; Kimball et al., 2002; Ainsworth and Long, 2004). No significant stimulation of yield has been found so far in $\mathrm{C}_{4}$ crops, at least under well-watered conditions, because $\mathrm{C}_{4}$ photosynthesis is saturated under ambient $\mathrm{CO}_{2}$ (Long et al., 2005). However, in all crops (both $\mathrm{C}_{3}$ and $\mathrm{C}_{4}$ ), higher $\mathrm{CO}_{2}$ concentrations reduce stomatal conductance and transpiration and improve wateruse efficiency, i.e. crops will experience a reduced demand for water.

\subsection{Direct effects on crop quality}

In comparison to air pollutant and climate change effects on crop growth and yield, much less is known about potential effects on the quality or the nutritive value, respectively, of agricultural and horticultural crops. Changes in crop quality due to $\mathrm{O}_{3}$ exposure have been studied in a limited number of crops. For example, in wheat, $\mathrm{O}_{3}$ reduced yield but increased grain protein concentration (Pleijel et al., 1999; Piikki et al., 2008). Moreover, $\mathrm{O}_{3}$ was found to have positive effects on the quality of potato tubers by decreasing reducing sugars and increasing the vitamin $\mathrm{C}$ content (Vorne et al., 2002). In contrast, $\mathrm{O}_{3}$ has been found to reduce the oil, protein and carbohydrate contents of the seeds of rape (Ollerenshaw et al., 1999). Recent evidence suggests that $\mathrm{O}_{3}$ can also alter the plant food quality for ruminant animals. Decreased nutritive quality of forages was found in a number of pasture species (Krupa et al., 2004; Bender et al., 2006).

Pollutant-induced visible injury is of particular significance when the quality and the marketable value of the crop depend on the appearance of the foliage, as is the case for a number of horticultural crops. For example, Kostka-Rick et al. (2002) have shown that environmentally-relevant concentrations of $\mathrm{O}_{3}$ can cause visible foliar injury on species such as lettuce, 


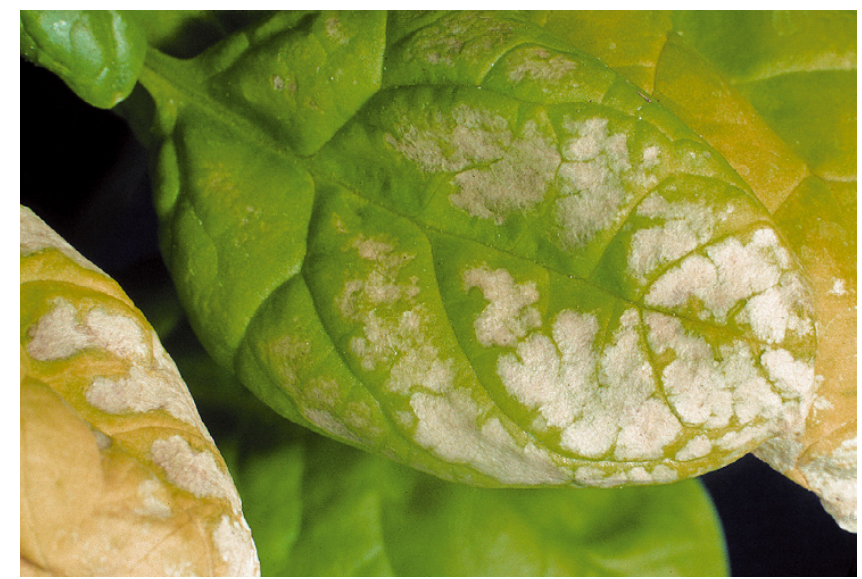

Figure 3. Ozone injury on spinach (Spinacea oleracea cv. Matador). Courtesy: J. Bender, vTI Braunschweig, Germany.

spinach or onion, which would make these crops unmarketable (Figs. 3 and 4).

A frequently observed phenomenon is that plants grown at high $\mathrm{CO}_{2}$ levels exhibit significant changes in their chemical composition (Idso and Idso, 2001; Loladze, 2002). A prominent example of a $\mathrm{CO}_{2}$ effect is the decrease in the nitrogen $(\mathrm{N})$ concentration in vegetative plant parts as well as in seeds and grains and, related to this, the decrease in the protein concentrations (Cotrufo et al., 1998; Taub et al., 2008; Wieser et al., 2008). Other $\mathrm{CO}_{2}$ enrichment studies have shown changes in the composition of other macro- and microelements $(\mathrm{Ca}, \mathrm{K}$, $\mathrm{Mg}, \mathrm{Fe}, \mathrm{Zn}$ ) and in concentrations of secondary compounds, vitamins and sugars (Idso and Idso, 2001). Overall, these $\mathrm{CO}_{2}-$ induced changes may have negative consequences with respect to nutritional quality of foods and feeds, the plant-herbivore interaction and the element turnover of ecosystems, respectively. The examples above indicate that there may be economically important effects of air pollution and climate changes on the quality of crops and forage species, although the available information is still inconsistent.

\subsection{Interactive effects of atmospheric compounds}

Under field conditions plants are exposed to different environmental factors including more than only one atmospheric compound. Based primarily on experimental work it has been shown that mixtures of atmospheric compounds and air pollutants, respectively, modify the magnitude and nature of the response to individual compounds. Generally, pollutant combinations may result in either more-than-additive (synergistic) or less-than-additive (antagonistic) effects. Based on the prevailing conditions at that time interactions of $\mathrm{O}_{3}$ with other air pollutants (e.g., $\mathrm{SO}_{2}, \mathrm{NO}_{2}$ ) were studied quite frequently in the 1980s (reviewed by Fangmeier et al., 2002). Currently, at least for Europe and North America, a simultaneous occurrence of $\mathrm{O}_{3}, \mathrm{SO}_{2}, \mathrm{NO}_{2}$ or $\mathrm{NH}_{3}$ at phytotoxic levels is rather unusual and far less frequent than sequential or combined sequential/concurrent exposures. From experiments where ex-

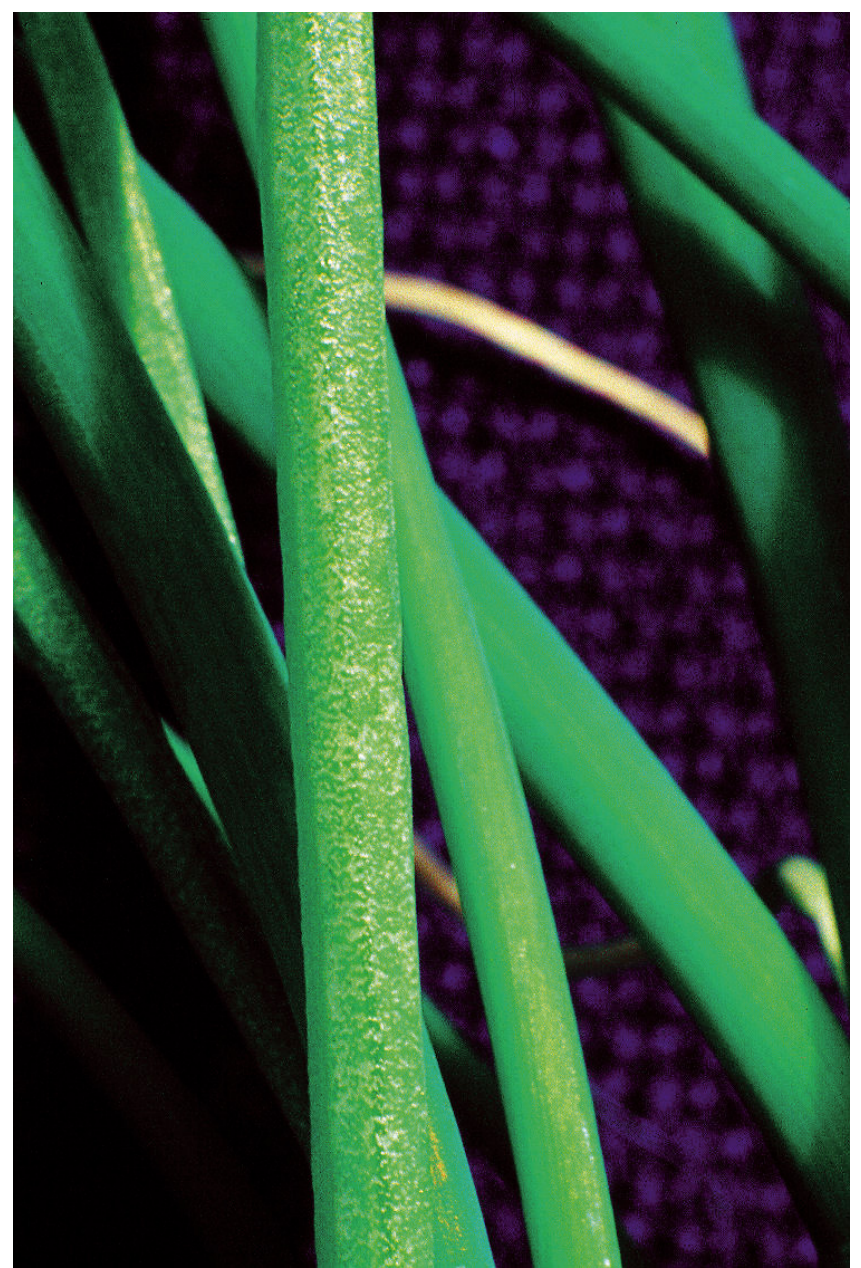

Figure 4. Ozone injury on spring onion (Allium fistulosum cv. Polo). Courtesy: J. Bender, vTI Braunschweig, Germany.

posure conditions have been more realistic in terms of their likelihood of occurrence in ambient air it can be concluded that: (1) antagonistic interactions tend to be found when gases were applied sequentially (e.g., $\mathrm{O}_{3} / \mathrm{NO}_{2}$ ) and/or when, e.g., nitrogenous or sulphurous air pollutants were combined with $\mathrm{O}_{3}$ at relatively low levels, suggesting that plants were able to utilise the additional $\mathrm{S}$ or $\mathrm{N}$ source; and (2) synergistic interactions are more likely to be found when $\mathrm{O}_{3}$ was applied simultaneously with another pollutant at high concentrations (Fangmeier and Bender, 2002). For the situation in Europe and North America this would imply that neither $\mathrm{SO}_{2}$ nor $\mathrm{NO}_{2}$ seems likely to pose an additional risk to that related to $\mathrm{O}_{3}$. However, the effects of pollutant combinations on crop growth and yield should have a much higher significance in many developing countries where air pollutants such as $\mathrm{SO}_{2}, \mathrm{NOx}$ and $\mathrm{O}_{3}$ are rapidly increasing (Ishii et al., 2007).

With respect to the future there is some evidence that elevated $\mathrm{CO}_{2}$ has the potential to mitigate negative effects of $\mathrm{O}_{3}$ (and other gaseous pollutants), mainly due to a $\mathrm{CO}_{2}$ induced reduction in stomatal conductance, which reduces $\mathrm{O}_{3}$ uptake. On the other hand, $\mathrm{O}_{3}$ limits positive $\mathrm{CO}_{2}$ responses in 
many plants as well (Fiscus et al., 2005). All climate change factors, such as $\mathrm{CO}_{2}$, warming, changes in precipitation, etc., which may affect stomatal conductance and thus the flux of gaseous air compounds into leaves, will exert a modification on the effects of individual pollutants (Bender and Weigel, 2003; Harmens et al., 2007). In summary, the available information suggests that the continuing increases in the $\mathrm{CO}_{2} \mathrm{com}$ ponent of climate change are likely to be ameliorative for the effects of air pollutants. Although there is some evidence that the concomitant increases in mean global temperature may decrease these protective effects (Fuhrer, 2003; USEPA, 2006), it is still not possible to predict the combined impacts of climate change and air pollutants on crops.

\subsection{Indirect effects}

Atmospheric compounds and air pollutants, respectively, may interact with other biotic and abiotic growth or stress factors (e.g., water and nutrient supply; heat and water stress; salinity, pesticide application; pests and pathogens; symbiotic relationships) in a complex manner, thus causing indirect effects on crop performance. For example, while it is well accepted that reduced vitality due to $\mathrm{O}_{3}$ stress can make plants more susceptible to plant pathogens, general predictions of $\mathrm{O}_{3}$ effects on particular plant-pathogen systems are difficult, because the available data for specific pests and diseases are often controversial (USEPA, 2006; Fuhrer, 2009). Increased susceptibility after $\mathrm{O}_{3}$ exposure has been reported for necrotrophic pathogens, while obligate biotrophic infections tend to be diminished by $\mathrm{O}_{3}$ (Manning and von Tiedemann, 1995; USEPA, 2006). With regard to insect pathogens, there is a general trend that some pests may have a preference for and grow better when feeding on $\mathrm{O}_{3}$-stressed plants, but there are also other observations where insect growth was not changed (USEPA, 2006). Viral infection often provides some protection from $\mathrm{O}_{3}$ injury; however, the type and degree of protection depend on the specific host and virus (Manning and von Tiedemann, 1995).

The direct effects of elevated $\mathrm{CO}_{2}$ levels on tissue chemical composition can have an indirect effect on plant-herbivore interactions, as host plants growing under enriched $\mathrm{CO}_{2}$ environments usually exhibit, e.g., decreased tissue $\mathrm{N}$ concentration, increased $\mathrm{C} / \mathrm{N}$ ratios and generally altered secondary metabolism of C-based secondary and structural compounds. This in turn may affect food consumption by herbivores and related population development (Stiling and Cornelissen, 2007). However, there is almost no information about how $\mathrm{O}_{3}$ effects on plant-pathogen systems may be modified in a future climate with elevated $\mathrm{CO}_{2}$ (Chakraborty et al., 2000; Fuhrer, 2009). For example, while host plants growing under enriched $\mathrm{CO}_{2}$ environments usually exhibit larger biomass, increased $\mathrm{C} / \mathrm{N}$ ratios and decreased tissue $\mathrm{N}$ concentration, $\mathrm{O}_{3}$ has the opposite effect (Pleijel et al., 1999; Piikki et al., 2008). Hence, it remains open how food consumption by herbivores and population development are affected under future atmospheric conditions characterised by elevated $\mathrm{O}_{3}$ and $\mathrm{CO}_{2}$ concentrations (Stiling and Cornelissen, 2007).
Another important interaction may occur between the effects of air pollutants and soil moisture availability. Water supply directly affects stomatal conductance and hence the uptake and effects of gaseous air pollutants. For example, it is known that reduced soil moisture limits $\mathrm{O}_{3}$ uptake by decreasing stomatal conductance, which increases $\mathrm{O}_{3}$ tolerance (Bender and Weigel, 2003). However, other findings suggest that, in some species, soil moisture stress may reduce rather than increase $\mathrm{O}_{3}$ tolerance (Bungener et al., 1999). The complex physiological and morphological changes due to water deficit impair plant vitality itself, e.g., by promoting senescence processes. Therefore, decreased pollutant uptake may not necessarily be connected with decreased pollutant injury. As outlined before (Sect. 3.1), elevated $\mathrm{CO}_{2}$ concentrations often improve water-use efficiency, i.e. may mitigate drought stress effects (Manderscheid and Weigel, 2007), which is an important feedback effect in future climate change scenarios.

Although the available information is clearly insufficient to understand the importance of interactions between air pollutants and biotic or abiotic factors, it is suggested that these indirect effects could be more important under certain circumstances than the direct effects of the gases on plants.

\section{CONCLUSION}

Crops, similarly to all other types of vegetation, are closely linked to the exchange of matter between the atmosphere and biosphere. After deposition of atmospheric compounds on canopies, crop growth and quality may be affected in various ways. Regarding the situation in most parts of Europe and North America, exposure to compounds such as $\mathrm{SO}_{2}$, $\mathrm{NO}_{2} / \mathrm{NO}$, VOCs and heavy metals is reduced and is currently not a major threat to crops. However, in many regions of both continents continuously increasing background levels of tropospheric $\mathrm{O}_{3}$ remain a problem, which poses an additional risk to crop growth and health during the growing season. In the growing economies of many developing countries the concentrations of atmospheric compounds such as $\mathrm{SO}_{2}, \mathrm{NOx}$, $\mathrm{NH}_{3}$ and particularly $\mathrm{O}_{3}$ are rapidly increasing. Already, these pollutants can lead to serious reductions of crop growth and yields, a situation which may be exacerbated in the future. Interactions with both biotic and abiotic factors must be taken into account in assessing risks of air pollutants in the field. On a global scale the rapid change in atmospheric composition by the increase in the atmospheric $\mathrm{CO}_{2}$ concentration accompanied by climate change has two major implications. A possible benefit to crop growth by direct stimulation of photosynthesis and by mitigation of gaseous air pollutants and water stress, but concomitantly a threat to crop production due to an enhancement of crop quality losses.

\section{REFERENCES}

Ainsworth E.A., Long S.P. (2005) What have we learned from 15 years of free-air $\mathrm{CO} 2$ enrichment (FACE)? A meta-analytic of the responses of photosynthesis, canopy properties and plant production to rising $\mathrm{CO}_{2}$, New Phytol. 165, 351-372. 
Amthor J.S. (2001) Effects of atmospheric $\mathrm{CO}_{2}$ on wheat yield: review of results from experiments using various approaches to control $\mathrm{CO}_{2}$ concentrations, Field Crops Res. 73, 1-34.

Ashmore M.R. (2005) Assessing the future global impacts of ozone on vegetation, Plant Cell Environ. 28, 949-964.

Bender J., Weigel H.-J. (2003) Ozone stress impacts on plant life, in: Ambasht R.S., Ambasht N.K. (Eds.), Modern Trends in Applied Terrestrial Ecology, Kluwer Academic/Plenum Publishers, New York, pp. 165-182.

Bender J., Muntifering R.B., Lin J.C., Weigel H.J. (2006) Growth and nutritive quality of Poa pratensis as influenced by ozone and competition, Environ. Pollut. 142, 109-115.

Bender J., Weigel H.J., Jäger H.J. (1991) Response of nitrogen metabolism in beans (Phaseolus vulgaris L.) after exposure to ozone and nitrogen dioxide, alone and in sequence, New Phytol. 119, 261-267.

Bungener P., Nussbaum S., Grub A., Fuhrer J. (1999) Growth response of grassland species to ozone in relation to soil moisture conditions and plant strategy, New Phytol. 142, 283-294.

Cape J.N. (2003) Effects of airborne volatile organic compounds on plants, Environ. Pollut. 122, 145-157.

Cape J.N., van der Eerden L.J., Sheppard L.j., Leith I.D., Sutton M.A. (2009) Evidence for changing the critical level for ammonia, Environ. Pollut. 157, 1033-1037.

Chakraborty S., von Tiedemann A., Teng P.S. (2000) Climate change: potential impact on plant diseases, Environ. Pollut. 108, 317-326.

Collins C.D., Bell J.N.B. (2002) Effects of volatile organic compounds, in: Bell J.N.B., Treshow M. (Eds.), Air pollution and plant life, John Wiley \& Sons, Chichester, pp. 173-186.

Cotrufo M.F., Ineson P., Scott A. (1998) Elevated $\mathrm{CO}_{2}$ reduces the nitrogen concentration of plant tissue, Glob. Change Biol. 4, 43-54.

Dämmgen U., Weigel H.J. (1998) Trends in atmospheric composition (nutrients and pollutants) and their interaction with agroecosystems, in: El Bassam N., Behl R., Prochnow B. (Eds.), Sustainable agriculture for food, energy and industry: strategies towards achievement, James \& James Science Publishers Ltd., London, pp. 85-93.

Davison A.W., Cape J.N. (2003) Atmospheric nitrogen compounds - issues related to agricultural sytems, Environ. Int. 29, 181-187.

Emberson L.D., Ashmore M.R., Murray F. (2003) Air Pollution Impacts on Crops and Forests: a Global Assessment, Imperial College Press, London.

Fangmeier A., Bender J. (2002) Air pollutant combinations: significance for future impact assessments on vegetation, Phyton 42, 65-71.

Fangmeier A., Bender J., Weigel H.J., Jäger H.J. (2002) Effects of pollutant mixtures, in: Bell J.N.B., Treshow M. (Eds.), Air pollution and plant life, John Wiley \& Sons, Chichester, pp. 251-272.

Fiscus E.L., Booker F.L., Burkey K.O. (2005) Crop responses to ozone: uptake, modes of action, carbon assimilation and partitioning, Plant Cell Environ. 28, 997-1011.

Fowler D., Sutton M.A., Flechard C., Cape J.N., Storeton-West R., Coyle M., Smith R.I. (2001) The control of $\mathrm{SO}_{2}$ dry deposition on natural surfaces and its effects on regional deposition, Water Air Soil Pollut.: Focus 1, 39-48.

Fu B.J., Zhuang X.L., Jiang G.B., Shi J.B., Lü Y.H. (2007) Environmental problems and challenges in China, Environ. Sci. Technol. 41, 7597 7602.

Fuhrer J. (2003) Agroecosystem responses to combinations of elevated $\mathrm{CO}_{2}$, ozone, and global climate change, Agric. Ecosyst. Environ. $97,1-20$.

Fuhrer J. (2009) Ozone risk for crops and pastures in present and future climates, Naturwissenschaften 96, 173-194.
Ghude S.D., van der A.R.J., Beig G., Fadnavis S., Polade S.D. (2009) Satellite derived trends in $\mathrm{NO}_{2}$ over the major global hotspot regions during the past decade and their inter-comparison, Environ. Pollut. 157, 1873-1878.

Grübler A. (2003) Trends in global emissions: Carbon, sulfur, and nitrogen, in: Douglas I. (Ed.), Encyclopedia of global environmental change. Vol 3: Causes and consequences of global environmental change, John Wiley \& Sons, Chichester, pp. 35-53.

Harmens H., Mills G., Emberson L.D., Ashmore M.R. (2007) Implications of climate change for the stomatal flux of ozone: A case study for winter wheat, Environ. Pollut. 146, 763-770.

Harmens H., Norris D. and the participants of the moss survey (2008) Spatial and temporal trends in heavy metal accumulation in mosses in Europe (1990-2005), Programme Coordination Centre for the ICP Vegetation, Bangor, UK.

Holland M., Kinghorn S., Emberson L., Cinderby S., Ashmore M., Mills G., Harmens H. (2006) Development of a framework for probabilistic assessment of the economic losses caused by ozone damage to crops in Europe, CEH Project No. C02309NEW, Report to U.K, Department of Environment, Food and Rural affairs.

Idso S.B., Idso K.E. (2001) Effects of atmospheric $\mathrm{CO}_{2}$ enrichment on plant constituents related to animal and human health, Environ. Exp. Bot. 45, 179-199.

IPCC (Intergovernmental Panel on Climate Change) (2007) The 4th Assessment Report. Working Group I Report: The physical scientific basis. www.ipcc.ch.

Ishii S., Bell J.N.B., Marshall F.M. (2007) Phytotoxic risk assessment of ambient air pollution on agricultural crops in Selangor State, Malaysia, Environ. Pollut. 150, 267-279.

Ishii S., Marshall F.M, Bell J.N.B., Abdullah A.M. (2004) Impact of ambient air pollution on locally grown rice cultivars (Oryza sativa L.) in Malaysia, Water Air Soil Pollut. 154, 187-201.

Kesselmeier J., Staudt M. (1999) Biogenic volatile organic compounds (VOC): an overview on emission, physiology and ecology, J. Atmos. Chem. 33, 23-88.

Kimball B.A., Kobayashi K., Bindi M. (2002) Responses aof agricultural crops to free-air $\mathrm{CO}_{2}$-enrichment, Adv. Agron. 77, 293-368.

Kostka-Rick R., Bender J., Bergmann E., Weigel H.J. (2002) Symptoms of ozone-induced foliar injury on horticultural crops, in: Klumpp A., Fomin A., Klumpp G., Ansel W. (Eds.), Bioindication and air quality in European cities, G. Heimbach, Stuttgart, pp. 191-196.

Krupa S., Booker F., Bowersox V., Lehmann C.T., Grantz D. (2008) Uncertainties in the current knowledge of some atmospheric trace gases associated with US agriculture: A review, J. Air Waste Manage. Assoc. 58, 986-993.

Krupa S., Muntifering R., Chappelka A. (2004) Effects of ozone on plant nutritive quality characteristics for ruminant animals, The Botanica $54,1-12$.

Krupa S.V. (1997) Air pollution, people, and plants, APS Press, St. Paul, MN, USA.

Legge A.H., Jäger H.J., Krupa S.V. (1998) Sulfur dioxide, in: Flagler R.B. (Ed.), Recognition of air pollution injury to vegetation: A pictorial atlas, Air Waste Manage. Assoc., Pittsburgh, Pennsylvania, USA, Chap. 3, pp. 1-43.

Legge A.H., Krupa S.V. (2002) Effects of sulphur dioxide, in: Bell J.N.B., Treshow M. (Eds.), Air pollution and plant life, John Wiley \& Sons, Chichester, pp. 135-162.

Lendzian K.J., Kerstiens G. (1991) Sorption and transport of gases and vapors in plant cuticles, Reviews Environ. Contam. Toxicol. 121, $65-128$.

Loladze I. (2002) Rising atmospheric $\mathrm{CO}_{2}$ and human nutrition: toward globally imbalanced plant stoichiometry, Trends Ecol. Evol. 17, 457-461. 
Long S.P., Ainsworth E.A., Leakey A.D.B., Morgan P.B. (2005) Global food insecurity. Treatment of major food crops with elevated carbon dioxide or ozone under large-scale fully open.air conditions suggests recent models may have overestimated future yields, Philos. Trans. R. Soc. B 360, 2011-2020.

Manderscheid R., Weigel H.J. (2007) Drought stress effects on wheat are mitigated by atmospheric $\mathrm{CO}_{2}$ enrichment, Agron. Sustain. Dev. 27, 79-87.

Manning W.J., v. Tiedemann A. (1995) Climate change: Potential effects of increased atmospheric carbon dioxide $\left(\mathrm{CO}_{2}\right)$, ozone $\left(\mathrm{O}_{3}\right)$, and ultraviolet-B (UV-B) radiation on plant diseases, Environ. Pollut. 88, 219-245.

Marshall F.M. (2002) Effects of air pollutants in developing countries, in: Bell J.N.B., Treshow M. (Eds.), Air pollution and plant life, John Wiley \& Sons, Chichester, pp. 407-416.

Mills G., Buse A., Gimeno B., Holland M., Emberson L., Pleijel H. (2007) A synthesis of AOT40-based response functions and critical levels of ozone for agricultural and horticultural crops, Atmos. Environ. 41, 2630-2643.

Ollerenshaw J.H., Lyons T., Barnes J.D. (1999) Impacts of ozone on the growth and yield of field grown winter oilseed rape, Environ. Pollut. $104,53-59$.

Piikki K., De Temmerman L., Ojanperä K., Danielsson H., Pleijel H. (2008) The grain quality of spring wheat (Triticum aestivum L.) in relation to elevated ozone uptake and carbon dioxide exposure, Eur. J. Agron. 28, 245-254.

Pleijel H., Mortensen L., Fuhrer J., Ojanpera K., Danielsson H. (1999) Grain protein accumulation in relation to grain yield of spring wheat (Triticum aestivum L.) grown in open-top chambers with different concentrations of ozone, carbon dioxide and water availability, Agric. Ecosyst. Environ. 72, 265-270.

Prather M., Gauss M., Berntsen T., Isaksen I., Sundet J., Bey I., Brasseur G., Dentener F., Derwent R., Stevenson D., Grenfell L., Hauglustaine D. Horowitz L., Jacob D., Mickley L., Lawrence M., von Kuhlmann R., Muller J., Pitari G., Rogers H., Johnson M., Pyle J., Law K., van Weele M., Wild O. (2003) Fresh air in the 21st century, Geophys. Res. Lett. 30, 1-4.

Royal Society (2008) Ground-level ozone in the 21st century: future trends, impacts and policy implications, Science Policy Report 15/08, The Royal Society, London.

Stiling P., Cornelissen T. (2007) How does elevated carbon dioxide $\left(\mathrm{CO}_{2}\right)$ affect plant-herbivore interactions? A field experiment and metaanalysis of $\mathrm{CO}_{2}$-mediated changes on plant chemistry and herbivore performance, Glob. Change Biol. 13, 1823-1842.
Taub D.R., Miller B., Allen H. (2007) Effects of elevated $\mathrm{CO}_{2}$ on protein concentration of food crops: a meta-analysis, Glob. Change Biol. $14,1-11$.

UNECE (United Nations Economic Commission for Europe) (2004) Manual on methodologies and criteria for Modelling and Mapping Critical Loads and Levels an Air Pollution Effects, Risks and Trends, www.icpmapping.org.

UNECE (United Nations Economic Commission for Europe) (2007) Review of the Gothenburg Protocol. Report of the Task Force on Integrated Assessment Modelling and the Centre for Integrated Assessment Modelling, CIAM report 1/2007, Bilthoven, Laxenburg.

USEPA (US Environmental Protection Agency) (2006) Air Quality Criteria for Ozone and Related Photochemical Oxidants, Report no. EPA/600/R-05/004aF-cF, US Environmental Protection Agency, Washington, DC.

Vandermeiren K., Harmens H., Mills G., De Temmerman L. (2009) Impacts of ground level ozone on crop production in a changing climate, in: Singh S.N. (Ed.), Climate Change and Crops, Environmental Science and Engineering, Springer, Berlin, pp. 213243.

Van Dingenen R., Dentener F.J., Raes F., Krol M.C., Emberson L., Cofala J. (2009) The global impact of ozone on agricultural crop yields under current and future air quality legislation, Atmos. Environ. 43, 604-618.

Vingarzan R. (2004) A review of surface ozone background levels and trends, Atmos. Environ. 38, 3431-3442.

Vorne V., Ojanpera K., DeTemmerman L., Bindi M., Högy P., Jones M.B., Lawson T., Persson K. (2002) Effects of elevated carbon dioxide and ozone on tuber quality in the European multiple-site experiment CHIP-projekt, Eur. J. Agron. 17, 369-381.

Weigel H.J., Adaros G., Jäger H.J. (1990) Yield responses of different crop species to long-term fumigation with sulfur dioxide in opentop chambers, Environ. Pollut. 67, 15-28.

Wellburn A.R. (1990) Why are atmospheric oxides of nitrogen usually phytotoxic and not alternative fertilizers? New Phytol. 115, 395429.

Wellburn A.R. (1994) Air pollution and climate change, Longman Scientific and Technical, New York.

Wieser H., Manderscheid R., Erbs M., Weigel H.J. (2008) Effects of elevated $\mathrm{CO}_{2}$ concentrations on the quantitative protein composition of wheat grain, J. Agric. Food Chem. 56, 6531-6535. 